\title{
Um mapa para se estudar Chico Buarque
}

Walter Garcia*

Chico Buarque

Fernando de Barros e Silva, Publifolha, 2004.

Sabe-se que não é tarefa fácil interpretar toda a obra de Chico Buarque de Holanda - canções, peças teatrais e romances, sem contar uma novela -, tendo ainda a preocupação de valorizar "algumas passagens marcantes" da vida do artista, celebrando os 60 anos que ele então completava, em um livro de bolso. E é prudente que um projeto assim, seja quais forem seus acertos ou lacunas, se anuncie como "uma tentativa parcial de interpretação do autor e sua obra" (p. 9). Penso que talvez se possa comparar sua realização a um traçado cartográfico: se o texto conseguir, por um lado, recolher as melhores informações de que se dispõe até o momento e, por outro, apontar para desdobramentos de análise possiveis, em outros mapas que se tirem com as minúcias necessárias, terá cumprido bem sua função.

Chico Buarque, de Fernando de Barros e Silva, tem precisamente esse caráter, constituindo-se um mapeamento útil e inteligente do tema, em que pese a brevidade própria de um volume da série Folha Explica, em sua ambição de se oferecer tanto "para o leitor geral" como para "quem domina os assuntos" (p.178).

Silva afirma, na Apresentação (p. 9), que seu trabalho se sustenta "por uma idéia que de alguma maneira organiza as demais", idéia essa elucidada em seus termos "já no primeiro capítulo": "Sua figura [de Chico] reúne o sonho do compromisso e da identidade entre uma elite esclarecida e um povo que enfim teria encontrado seu lugar e destino. Se há um fio vermelho que atravessa e unifica sua obra imensa e variada é aquele que faz dela ao mesmo tempo registro e memória do 'país da delicadeza perdida'. (...) Sua música é expressão de uma promessa histórica e testemunho de suas sucessivas frustrações” (pp. 16-17).

Mais do que para a idéia em si, gostaria inicialmente de chamar a atenção para a forma como ela se constrói. No

\footnotetext{
* Walter Garcia é doutor em Literatura Brasileira pela FFLCH-USP, professor da PUC-SP e músico popular. É autor de Bim Bom: a contradição sem conflitos de João Gilberto (São Paulo: Paz e Terra, 1999).
} 
meu modo de entender, temos aqui o primeiro exemplo de um tipo de raciocínio bastante responsável pelos momentos mais interessantes do ensaio. Mantém-se um olho no artista, outro na sua produção, intenção já referida. Mas também se olha a história brasileira na qual ambos surgem, da qual ambos participam e a qual ambos refletem de um modo peculiar. Assim, a investigação que vai do processo histórico ao conjunto autor-obra (e vice-versa) se dá dialeticamente, na tradição dos estudos que buscam esclarecer o sentido de uma trajetória artística singular interpretando-a no todo de um contexto histórico-cultural. E (outra vez) vice-versa, pois se busca igualmente esclarecer o sentido de um contexto histórico-cultural por meio da interpretação de uma determinada trajetória artística.

Há nisso tudo uma evidente e não disfarçada influência sobretudo do trabalho de Roberto Schwarz. A afirmação, entenda-se, não é elogio nem reprovação, mas um dado relevante para que se compreenda melhor o ensaio. Já em um comentário anterior de Fernando de Barros e Silva sobre Arrigo Barnabé, incluído em outro volume da mesma série, ${ }^{1}$ a análise se construía como um exercício dialético. Diga-se de passagem, um comentário de muita acuidade que, em apenas três páginas, sintetizava admiravelmente a questão central de três décadas de composição de Arrigo. No entanto, para os leitores de Schwarz era bastante curioso deparar-se lá com o seguinte parágrafo:

"A obsessão pelo kitsch nessa música merece uma nota à parte. $O$ balcão de fórmica vermelha, a calcinha imitando pele de leopardo, o drink no drive-in, as balas collored - há ai, nessa enumeração aleatória, um mosaico de referências que, sendo grotescas ou simplesmente cafonas, aspiram à elegância. É nesse descompasso que reside a sua graça. O leitor dirá se é exagerado vê-los todos como exemplos palpáveis de uma promessa de vida burguesa que desandou e degenerou em cortiço. Clara Crocodilo é a crônica sarcástica do encortiçamento da cultura e dos centros nervosos do país. Mais contemporâneo, impossivel",

no qual, até que se chegasse à última frase - talvez destoante das outras por ser quase um clichê jornalístico -, os termos e as expressões, a sintaxe, a forma de armar o pensamento e o próprio salto interpretativo ecoavam certo estilo de Roberto Schwarz. Não é isso o que se nota no livro Chico Buarque. Nele a influência vem explicitada em notas de rodapé. Não me refiro especialmente ao artigo

1 Cf. Música popular brasileira hoje, organizado por Nestrovski, Arthur. São Paulo, Publifolha, 2002, pp. 38-41. 
de Schwarz sobre Estorvo servir tanto às observações de Silva acerca desse romance como para fechar o comentário das canções "Pivete", "O meu guri" e "Brejo da Cruz", pois há outros autores utilizados de modo mais fundamental na visão que se apresenta de artista e obra. 0 que ocorre é que o sentido do processo histórico brasileiro é percebido com base principalmente em interpretações de Roberto Schwarz que, como se sabe, em seu trabalho procura articular forma artística e dinâmica social - método aliás que Antonio Candido, para ficarmos no âmbito brasileiro, já iniciara anteriormente. $^{2}$

Há, entretanto, uma importante diferença de metodologia a assinalar entre os estudos desses dois críticos literários e o livro de Fernando de Barros e Silva. Em sua abordagem, Silva não desenvolve uma análise da estrutura interna das obras com vistas a, nos termos de Candido, levar em conta o elemento social "como fator da própria construção artística, estudado no nível explicativo e não ilustrativo". ${ }^{3}$ À parte o tipo de publicação exigir por vezes uma concisão extremada, a análise estética em Chico Buarque fica circunscrita ao comentário perspicaz sobre letras de canções (em relação à parte musical, falarei adiante) e enredos de livros, refletindo basicamente sobre seus conteúdos, não sobre suas formas (com o perdão pela linguagem ultrapassada).

Uma apreciação, portanto, que não chega a ser uma crítica no sentido rigoroso da palavra, ficando entre o ensaio sociológico e a interpretação jornalística - já que esta última é cada vez mais rara na imprensa, dedicada a copiar ou redigir releases, quando não a fazer circular a marca do veículo ou o marketing pessoal do jornalista, pode-se cogitar que a série Folha Explica seja oferecida pela empresa Folha da Manhã como sucessora de um espaço que, de fato nunca muito extenso, anda hoje em vias de extinção. A estratégia nem é propriamente uma novidade, se lembrarmos que já há algum tempo a grande reportagem se tornou basicamente um gênero de livro. Para quem se interessa por conheci-

2 Sobre o assunto, ver Arantes, Paulo Eduardo. Sentimento da dialética na experiência brasileira: dialética e dualidade segundo Antonio Candido e Roberto Schwarz. Rio de Janeiro, Paz e Terra, 1992.

3 Cf. Candido, Antonio. "Crítica e Sociologia". Literatura e sociedade. São Paulo, T. A. Queiroz/ Publifolha, 8a edição, 2000, p. 8. A questão também foi discutida na clássica introdução de Formação da literatura brasileira (vol. 1). 7a ed. Rio de Janeiro/Belo Horizonte, Itatiaia, 1993, pp. 23-37. De Roberto Schwarz, entre outros textos, vale destacar "Pressupostos, salvo engano, de 'Dialética da malandragem'. Que horas são?, São Paulo, Companhia das Letras, 1987, pp. 129-155. Caso se prefira ver o método na prática, creio que "A carroça, o bonde e o poeta modernista" seja um bom exemplo (Idem, pp. 11-28), ensaio aliás citado por Fernando de Barros e Silva, à p. 51. 
mento, entretanto, a questão que se coloca é em que medida essa alteração contribui para aprofundar o texto jornalístico interpretativo e em que medida ela acaba rebaixando o nível da reflexão crítica.

\section{Quatro contribuições}

Em seus aspectos mais positivos, a perspectiva adotada no trabalho de Silva apresenta quatro boas contribuições, na minha opinião. Número um, os apontamentos sobre as "Raízes de Chico", que colocam obra e artista em relação a duas utopias. De um lado, "uma espécie de utopia estética" aprendida com Tom Jobim e Oscar Niemeyer: "a ilusão de que a mesma chave que podia reparar as injustiças de uma herança histórica pesada serviria também para abrir as portas da nossa modernidade”. A chave de que se fala seria a conciliação de nossos vários antagonismos ("o local e o cosmopolita, o sertão e o litoral, o folclore e a vanguarda, o popular e o erudito"), em um projeto "coletivo, ainda que difuso" de integração nacional, do qual Brasília "seria a síntese, a materialização”. 0 problema é que somente o sentido histórico dessa utopia é apresentado, não se descrevendo como ela se deu esteticamente ou, em outras palavras, como ela era para ter o sentido histórico que tem. De modo análogo, a alusão feita a Guimarães Rosa nesse quadro é válida, e acredito que acertada, mas tampouco descreve, apenas exemplifica (p. 15).

De outro lado, haveria uma "utopia social" herdada de Sérgio Buarque: "a crença de que a construção de um país viável dependia e passava pela adoção de uma democracia de massas, na qual a maioria pobre tivesse a liderança do processo histórico" (p. 26; grifo do autor), sobre o quê, há um aspecto a ser debatido mais adiante.

Contribuição número dois do livro de Silva, a utilização de quase quarenta anos de entrevistas de Chico muitas delas disponíveis no site oficial dedicado ao artista (www.chicobuarque.com.br), uma ótima fonte de pesquisa -, além dos perfis escritos pelos jornalistas Humberto Werneck e Regina Zappa ${ }^{5}$ e de depoimentos dados ao próprio autor. Há desde entrevistas já meio míticas, como a para o Pasquim em 1970, até comentários mais recentes, como o sobre

4 Os termos são de Chico Buarque, em entrevista citada por Fernando de Barros e Silva; todos os outros trechos que transcrevo na passagem, inclusive o grifo, são de Silva, pp. 15-16.

5 Werneck, Humberto. "Gol de letras". Buarque, Chico. Chico Buarque, letra e música (vol. 1). São Paulo, Companhia das Letras, 1989. Zappa, Regina. Chico Buarque: para todos. Rio de Janeiro, Relume Dumarál Prefeitura, 1999. 
o uso escamoteado da seleção de futebol húngara de 1954 em Budapeste, "brincadeira, aparentemente gratuita, [que] se integra à engenharia do romance, todo ele construído como um jogo de espelhos em torno de identidades fugidias e cambiáveis", na ótima observação de Silva (p. 108). A reunião e o aproveitamento de todo esse material é um trabalho jornalístico muito bem realizado que também revela um esforço de acumulação, sem o qual há sempre o risco da mera repetição de idéias anteriores, ou de o conhecimento da questão tratada não avançar como poderia.

Um rápido parêntese. Se não estou enganado, esse é um problema encontrado no texto "A utopia lírica de Chico Buarque de Hollanda”, de Renato Janine Ribeiro, que expõe, aparentemente sem saber, algumas idéias semelhantes às de Adélia Bezerra de Meneses, Walnice Nogueira Galvão, José Miguel Wisnik e Guilherme Wisnik. Não se trata de plágio, entenda-se bem, e é verdade que o trabalho se constrói a partir de um novo ângulo de observação - a tradição filosófica -, o que realmente enriquece o que já se sabia, à parte o enriquecimento garantido pela qualidade de seu próprio autor. No entanto, estou certo de que, caso tivesse considerado seus pares, o texto teria levado mais longe reflexões como: "a transgressão é justamente o que formula a utopia de Chico Buarque"; "o samba, ou o amor, ou o Eros, é o ponto que pode efetuar essa grande transformação social"; e "o que temos em Chico Buarque será a conversão - sempre recíproca, sempre em duas mãos - do íntimo e do pessoal, no coletivo e no social". Além disso, parece-me realmente injustificado Janine Ribeiro não mencionar a célebre noção de cordialidade apresentada por Sérgio Buarque mesmo observando que, nas canções de Chico, a utopia "passa por um recuo da lei, no seu teor repressor", pois nessa utopia "o fator que liberta é a intensificação dos elementos amorosos ou afetuosos". ${ }^{6}$

Publicado no mesmo ano, o livro de Fernando de Barros e Silva apresenta uma disposição diversa, como já foi

6 Cf. Ribeiro, Renato Janine. "A utopia lírica de Chico Buarque de Hollanda”. Cavalcante, Berenice; Starling, Heloísa \&t Eisenberg, José (orgs.), Decantando a República, volume 1: Outras conversas sobre os jeitos da canção. Rio de Janeiro, Nova Fronteira/ São Paulo, Ed. Fundação Perseu Abramo, 2004, pp. 149-168. 0 texto de Walnice Nogueira Galvão a que me refiro é "MMPB: uma análise ideológica”. Sacos de gatos. 2a ed. São Paulo: Duas Cidades, 1976, pp. 93-119. A noção de cordialidade é formulada por Sérgio Buarque de Holanda em Raízes do Brasil (3a ed. Rio de Janeiro: José Olympio, 1956). Sobre os textos dos outros autores, ver notas 7, 8 e 10. Ressalte-se que, na mesma série em que se encontra o texto de Janine Ribeiro, Heloísa Starling nos apresenta um bom exemplo de interpretação de Chico Buarque construída a partir de esforços anteriores (cf. "Uma República pelas tabelas”; Decantando a República, volume I1: Retrato em branco e preto da nação brasileira, pp. 105-116). 
falado, à qual também se liga a sua terceira contribuição. Depois de haver enunciado a articulação, na obra de Chico, entre uma utopia estética e uma utopia social, ambas historicamente cortadas pelo golpe de 1964, o trabalho formula aquela "idéia que de alguma maneira organiza as demais": em suas canções, Chico "faz como se escrevesse a história duas vezes, nos revelando o que somos e aquilo que não nos tornamos" (p. 17). E a ela seguem-se outros raciocínios, também construídos dialeticamente: a obra de Chico Buarque se dá na intersecção entre a experiência coletiva e a subjetividade (p. 17); trata-se de um escritor que registra a História mas, nas suas próprias palavras, não consegue "escrever coisa que não seja ficção", um escritor cuja prosa, para Silva, "se resolve em poesia" (p. 18); o lirismo das suas primeiras canções, no pós-golpe de 64, assinala uma utopia que se opõe criticamente à realidade, utopia cuja felicidade é nostálgica, "fugaz e sempre relacionada a motivos musicais e próprios da cultura popular": "0 poeta desencantado canta - e no seu canto traz de volta por um instante - algo que se perdeu" (pp. 41-42).

\section{Aprimorando o conhecimento}

Ocorre que todas essas idéias foram concebidas com base no aprofundamento de textos anteriores. A idéia principal defendida por Silva tem como matrizes o ensaio "0 artista e o tempo", de José Miguel Wisnik e Guilherme Wisnik, ${ }^{7}$ e o artigo "Estorvo", de Marcelo Coelho, ${ }^{8}$ devendo-

7 Cf. Winsnik, José Miguel e Wisnik, Guilherme, "0 artista e o tempo". Wisnik, J. M. Sem receita. São Paulo, Publifolha, 2004, pp. 241-259. (Publicado anteriormente em Songbook Chico Buarque, vol. 2. Rio de Janeiro: Lumiar, 1999, pp. 8-20.) Desse ensaio Fernando de Barros e Silva também extraiu e desenvolveu outras sugestões importantes como a abordagem, nas canções, "da emergência lenta e gradual dos pivetes ('Pivete' [em parceria com Francis Hime], 1978, '0 meu guri', 1981, 'Brejo da cruz', 1984)" (cf. Wisnik, op. cit., p. 243) e o contraponto entre o compositor e o romancista (cf. Wisnik, pp. 248-249; Silva, pp. 116-117), assunto aliás tratado anteriormente pelo próprio Chico Buarque: "Eu sou o homem cordial. Eu sou um homem que age por impulso. Esse meu lado afetivo está talvez na música, que sofre esses arroubos afetivos. Eu faço uma distinção bastante clara: na literatura sou um cidadão sem afetos. 0 fato de estar solitário escrevendo um livro que vai ser apresentado em público, e que vai ser lido individualmente, isso me despe um pouco desse sujeito atirado e algo ingênuo. Já a música me emociona, eu fico em lágrimas. Eu sou um bobo como músico. Mas tenho o outro lado, racional e muito crítico, muito seco, que é um lado que quase não cabe na música, que precisa de outro veículo" (cf. "Chico Buarque volta ao samba e rememora 30 anos de carreira", entrevista a Augusto Massi, Folha de S. Paulo (Ilustrada), 9/1/1994, p. 6-5).

8 Cf. Coelho, Marcelo. “Estorvo”. Gosto se discute. São Paulo, Ática, 1994, pp. 61-65. (Publicado anteriormente na Folha de S.Paulo, 7/8/1991, com o título "Chico Buarque faz um livro impopular".) 
lhes a formulação, o que aliás é dito em notas de rodapé. A segunda idéia também é retirada de "0 artista e o tempo", e a terceira, agora sem indicação no rodapé, é parcialmente inspirada no release que José Miguel Wisnik escreveu para o lançamento do romance Budapeste. ${ }^{9}$ Mas não se trata de uma mera compilação, pois essas idéias sobre a trajetória artística de Chico Buarque são postas em diálogo com o contexto histórico-social tratado a partir de Roberto Schwarz. 0 resultado é que, no trabalho de Silva, as relações entre o artista, sua obra e o processo histórico ficam mais concretas do que estavam, melhorando-se o que se sabia até então. Embora não seja apresentada, reitere-se, uma análise estética com força de contraprova, o livro assinala de modo bem mais nítido um bom caminho para estudos subseqüentes.

Também a última idéia, acerca do potencial crítico do lirismo, retoma um estudo anterior, Desenho mágico, de Adélia Bezerra de Meneses. ${ }^{10}$ A propósito, Silva tem o cuidado de fazer três citações desse livro, acompanhando as três principais modalidades em que Meneses divide a canção de Chico: "lirismo nostálgico" (p. 42), "variante utópica" (p. 81) e "vertente crítica" (p. 71). ${ }^{11}$ Apenas a quarta modalidade ficou de fora, "canções de repressão", o que parece ser uma estratégia. 0 ensaio de Silva se mostra interessado em contestar a imagem pública de Chico Buarque como compositor de protesto, que lutou contra a ditadura militar durante a década de 1970 e, perseguido pela censura, foi o principal herói da esquerda. Trata-se de uma revisão que, à primeira vista bastante original, na verdade acompanha um desejo do artista manifestado em várias entrevistas desde aquela época, uma delas inclusive citada no próprio livro. Apesar disso, deve-se objetar que no fim das contas Silva dá muito pouca importância a um enfrentamento que, embora superdimensionado até agora, de fato existiu, à revelia ou não de seu protagonista.

9 "Budapeste, no exato instante em que termina, transforma-se em poesia". Cf. Wisnik, José Miguel. "O autor do livro (não) sou eu”, op. cit., p. 164. Outra passagem desse texto é citada por Fernando de Barros e Silva à p. 123 .

10 Cf. Meneses, Adélia Bezerra de. Desenho mágico. 2a ed. São Paulo, Ateliê Editorial, 2000. (1a ed., Hucitec, 1982.) A fim de complementar o que já se disse acerca de bases teóricas, vale lembrar que Meneses se apóia, entre vários textos diversos, em "Palestra sobre lírica e sociedade", de Theodor W. Adorno, conforme a autora explicita à p. 146. Esse texto de Adorno também é referido, mas apenas de passagem, por Fernando de Barros e Silva (p. 126).

110 fundamento para a divisão da obra de Chico Buarque - abordada como poesia de resistência - nessas três categorias vem de $O$ ser e o tempo da poesia, de Alfredo Bosi, conforme Meneses esclarece à p. 40, nota 18, de Desenho mágico. 
A quarta boa contribuição do livro de Fernando de Barros e Silva é o capítulo "Nem toda loucura é genial", que trata das relações entre a trajetória artística de Chico $\mathrm{Bu}$ arque e a dos tropicalistas, notadamente Caetano Veloso. Silva argumenta, uma vez mais em construção dialética, que Chico se torna alvo dos tropicalistas, na década de 1960, por conta da "complexidade de sua [de Chico] posição, difícil de enquadrar aqui ou ali, aliada à facilidade com que sua música se expressava, [o que] resultava numa figura ao mesmo tempo simples e sofisticada, popular e aristocrática, na qual a novidade do que fazia parecia incorporar o melhor da tradição que a inspirava" (pp. 55-56). E, após passar em revista quatro décadas, Silva aponta que Caetano e Chico descrevem movimentos contrários: em relação a Caetano, "sendo sempre diferente, sua obra será sempre a mesma"; sobre Chico, "sendo sempre a mesma, sua obra será sempre diferente" (grifos do autor; pp. 64-65).

Sistematizando as coisas, ainda que um tanto atropeladamente, nota-se que o "claro contraponto" entre as trajetórias "notáveis" de ambos apresenta, para Silva, uma base bem definida: se Caetano "segue rebolando conforme o ritmo do momento" 12 (p. 53); e se Chico tem uma atitude, herdada "do pai", "discreta e às vezes brincalhona, avessa aos alardes de si mesmo" (p. 22), bem como se ele conserva distância "deste país anômalo em que nos transformamos - meio novo-rico, sem deixar de ser meio miserável” (p. 53); essa diferença se dá porque Caetano adere com regozijo à mercantilização da arte, comportando-se como uma marca de carro ou de roupa que muda "de cor praticamente a cada estação, mas mantendo-se por isso mesmo sempre fiel à imagem tropicalista que inventou para si mesmo"13 (p. 64); enquanto Chico nos apresenta quase um enigma: "Não deixa de ser curioso que alguém tão consagrado esteja tão decididamente na contramão da cultura dominante e tão pouco à vontade com os ares do mundo" (p. 11).

Dessa visão procede a única divergência que Fernando de Barros e Silva assinala, num outro capítulo (p. 91), entre

12 Não deve ter sido essa a intenção de Fernando de Barros e Silva, mas sua escolha das palavras leva a frase, também no contexto original, a soar preconceituosa, como a alguns leitores pode ter parecido aqui.

13 Fernando de Barros e Silva não escreve "marca de carro ou de roupa", mas "camaleão", utilizando uma imagem que, cito de memória e posso estar enganado, o próprio Caetano Veloso forjou para si (não me refiro à canção "Rapte-me, Camaleoa", dedicada à atriz Regina Casé, mas a textos jornalísticos). A modificação aqui proposta, como se nota, sai do âmbito da natureza e procura sublinhar o caráter econômico-social da atuação de qualquer artista de mídia em nosso tempo. Devo a idéia a uma conversa informal com Milton Ohata, mas é evidente que a responsabilidade por uma idéia lançada em conversa ter sido escrita é apenas minha. 
o seu livro e o ensaio de José Miguel Wisnik e Guilherme Wisnik. Em "O artista e o tempo", os autores afirmaram que a letra de "Bye Bye, Brasil" (música de Roberto Menescal) corresponde "até certo ponto" à "profecia tropicalista", atribuindo sinal positivo a essa correspondência. Ocorre que, desde a década de 1970, os estudos de José Miguel Wisnik sobre canção popular sempre demonstraram, em graus diversos, uma atitude tropicalista de incluir a ambigüidade ou a ambivalência no método de interpretação, atitude fundada, entre outros aspectos, na percepção de que a realidade brasileira se estrutura de forma ambígua ou ambivalente. De fato, creio que não se possam entender, nesses estudos, as várias influências que o próprio Wisnik já listou - Antonio Candido, Roberto Schwarz, Davi Arrigucci Jr., Alfredo Bosi, José Antonio Pasta Jr. -, mesmo somadas à sua aproximação com a psicanálise e à sua formação musical, quando não se leva em conta a afinidade do ensaísta com "o espírito do tropicalismo baiano". ${ }^{14}$

Por sua vez, Fernando de Barros e Silva, acompanhando Roberto Schwarz, observa que "era impossível discernir em suas [dos tropicalistas] apostas, sempre muito entusiasmadas, onde terminava o esforço crítico e onde começava o oportunismo publicitário - até porque o próprio movimento tratava de confundir reiteradamente as duas coisas"15 (p. 52). A ambigüidade e a ambivalência, como se vê, nesse pensamento ganham sinal negativo. Ao afirmar,

14 As influências teóricas de José Miguel Wisnik são por ele comentadas em Wisnik, op. cit., pp. 526 a 531; as influências da tropicália e, em especial, de Caetano Veloso, são comentadas às pp. 490; 496; 501; 503 a 505. Note-se que já em 1985, escrevendo sobre Arrigo Barnabé, Wisnik assim considerava a situação geral da canção de massa no Brasil: "Caetano Veloso é quem mais tem essa cancha, historicamente conseguida, de midializar as mínimas sutilezas poéticas num máximo de referências culturais, que vão das mais literárias e eruditas ao samba, ao rock e ao brega. A sua capacidade de vazar a massificação trabalhando dentro dela é impressionante, e foi possível graças à conjunção entre o seu talento e o lugar privilegiado que a música ocupa no Brasil, seu trunfo e seu triunfo polêmico. Caetano se impregnou de tal modo da própria dinâmica geral da música popular brasileira, fazendo dela a sua matéria e o seu mito máximo, que se poderia aplicar a ele uma expressão de Lévi-Strauss no ‘Pensamento selvagem': o indivíduo como espécie, espécime único dotado de uma tal generalidade estrutural que nos faz crer que pertencem ao sistema da música popular atributos que são dele" (cf. "Inovação versus redundância na MPB", Folha de S.Paulo (Folhetim), 28/4/1985, p. 3).

15 Fernando de Barros e Silva, em nota de rodapé (p. 53), esclarece que a passagem se inspira em "Nacional por subtração", ensaio de Roberto Schwarz publicado em Que horas são?, o que fica evidente na frase seguinte à que transcrevi. Novamente se não estou enganado, contudo, também há a inspiração de "Cultura e política, 1964-1969: alguns esquemas" (citado por Silva à p. 37) e "Nota sobre vanguarda e conformismo", textos publicados por Schwarz em $O$ pai de família e outros estudos [2a ed. São Paulo: Paz e Terra, 1992]. 
portanto, que “'Bye Bye, Brasil' é antes o avesso da profecia tropicalista, ou sua critica interna pela exposição de sua realização histórica” (p. 91), Silva acaba retomando a histórica oposição Chico versus Caetano, tomando o partido do primeiro, note-se, num nível bem mais elevado do que propunha o velho clima de briga de torcidas uniformizadas: o que está em jogo, nessa análise, são dois projetos diferentes de nação.

No entanto, se o autor identifica na obra de Chico $\mathrm{Bu}-$ arque um claro "mal-estar" com o Brasil "que somos" e o Brasil "que não nos tornamos", restaria levar essa crítica adiante e investigar a curiosidade da consagração desse artista "tão pouco à vontade com os ares do mundo", o que Silva não faz. Este é o primeiro ponto, dentre dois, que eu gostaria de discutir, finalizando meu comentário.

\section{Duas discussões}

Ao posicionar a obra de Chico na tradição de um "pensamento radical" brasileiro, apoiando-se inteligentemente em considerações que Antonio Candido faz sobre Sérgio Buarque de Holanda, Silva defende a identificação daquele artista "com um radicalismo nada doutrinário, que tem na mobilização popular seu ponto de apoio” (pp. 26-27). Mas o lugar social desse radicalismo e os limites daí decorrentes não são pesquisados, o que é um passo atrás em relação às próprias reflexões em que Silva se baseia. Refirome à apresentação do radicalismo feita por Candido: "Gerado na classe média e em setores esclarecidos das classes dominantes, ele não é um pensamento revolucionário, e, embora seja fermento transformador, não se identifica senão em parte com os interesses específicos das classes trabalhadoras, que são o segmento potencialmente revolucionário da sociedade. (...) 0 revolucionário, mesmo de origem burguesa, é capaz de sair da sua classe; mas o radical, quase nunca. Assim, o revolucionário e o radical podem ter idéias equivalentes, mas enquanto o primeiro chega até a ação adequadas a elas, isto não acontece com o segundo, que em geral contemporiza na hora da ruptura definitiva". ${ }^{16}$

Sei que o texto de Candido, apresentado em 1988 e publicado pela primeira vez em 1990, para muitos recorre a um vocabulário e a um horizonte político atualmente sem razão de ser na dinâmica da economia mundial. Ainda que eu não concorde exatamente, aceito a objeção - mas meu contra-argumento é que qualquer análise posterior não deveria ignorar, e sim fazer avançar o que ali se diz, corri-

16 Cf. Candido, Antonio. "Radicalismos". Vários escritos. 3a ed. São Paulo, Duas Cidades, 1995, pp. 266-267. 0 texto é citado por Fernando de Barros e Silva na bibliografia. 
gindo o que parecesse necessário. Não seria um caminho adequado para um melhor entendimento sobre a consagração do artista?

Não se trata, entenda-se, de enxergá-lo sob o prisma de uma determinada atuação política, como muito já se fez. Trata-se de levar às últimas conseqüências o próprio método utilizado por Fernando de Barros e Silva. Há um silêncio, no livro, sobre o lugar específico da sociedade a partir do qual essa obra é produzida, no qual é bem veiculada e bem consumida, apesar (ou por causa?) do "mal-estar" representado. Por exemplo, diante de uma afirmação de Silva (p. 28) de que, a partir da década de 1980, "a conquista da democracia irá defrontar-se com o fato paradoxal de um país de agora em diante impossibilitado de realizar as promessas de que ela própria era portadora. Ficamos todos, por assim dizer, a ver navios - ou como passageiros da embarcação que 'navega para trás', na bela imagem do 'Xote de navegação' [parceria com Dominguinhos]”, resta a pergunta básica: a quem exatamente se refere o pronome "nós", aliás um sujeito oculto ${ }^{17}$

Nesse sentido, talvez seja sintomático que Silva acolha um pensamento exposto por Marcelo Coelho no artigo "Estorvo": "Se, nos países socialistas, a esquerda traiu o povo, o desespero com relação ao Brasil é inverso. De certo modo, o povo traiu a esquerda; o desespero, o rancor de Chico $\mathrm{Bu}-$ arque a partir dos anos 70, a referência não mais utópica, mas irônica, de suas canções depois dessa época significam, acima de tudo, a derrota que se abateu sobre um país que não se reconhece mais a si mesmo". ${ }^{18}$

17 A indicação de alguns outros textos de Antonio Candido talvez ajude a esclarecer minhas considerações. Veja-se, por exemplo, em Literatura e sociedade, o ensaio "0 escritor e o público", em que o autor relaciona, "na nossa literatura oitocentista", o desenvolvimento de "um certo conformismo de forma e fundo, apesar das exceções", ao "caráter, não raro assumido pelo escritor, de apêndice da vida social, pronto para submeter sua criação a uma tonalidade média, enquadrando a expressão numa certa bitola de gosto", tudo isso feito muitas vezes por "homens ajustados à superestrutura administrativa" (op. cit., p. 76); ou o ensaio "A literatura e a vida social", em que um dos tópicos discutidos é justamente "A posição do artista". No âmbito dos estudos sobre canção popular, veja-se "Seguindo a canção": engajamento politico e indústria cultural na MPB (1959-1969), de Marcos Napolitano [São Paulo, Annablume/Fapesp, 2001], trabalho praticamente isolado em seu propósito, realizado de modo excelente, de tentar "entender as formas concretas de atuação de artistas e intelectuais que acreditaram na possibilidade de engajar-se, ao mesmo tempo que atuavam no mercado musical” (p. 17).

18 Cf. Coelho, Marcelo. op. cit., pp. 63-64. 0 jornalista chega a esse pensamento a partir de duas comparações que faz, ambas aproveitadas por Fernando de Barros e Silva (pp. 44 e 63): uma, entre as canções "A banda" e "Vai passar" (parceria com Francis Hime); outra, entre "Quem te viu, quem te vê" e "Essa moça tá diferente". 
Em chave quase caricata, poderíamos lembrar uma fala de Terra em transe, de Glauber Rocha: “- O povo não tem culpa!” 0 caso, porém, é outro. Se, por um lado, o livro de Fernando de Barros e Silva silencia sobre a diversidade das forças históricas que atuaram na ruína daquela "promessa histórica" de que a obra de Chico é testemunho - o que requereria uma análise bem mais extensa e, desse modo, muito além dos limites impostos pelo tipo de publicação -, por outro, menciona-se uma traição do povo "a si mesmo" (na formulação de Silva, p. 44); restando então perguntar: de que lugar se atiram pedras no povo traidor?

Some-se a tudo isso um outro silêncio que há, quando se fala de "Assentamento". Como talvez algumas pessoas ainda recordem, a canção foi "feita para o livro Terra, do fotógrafo Sebastião Salgado, e depois [a mesma gravação foi] incluída em as cidades", nas palavras de Silva (p. 129). 0 que ele omite, porém, é que as fotografias retratam, conforme Sebastião Salgado esclarece nas legendas: "a dignidade e a pobreza" de trabalhadores brasileiros "de uma estrutura agrária ainda feudal”; famílias de retirantes, em período de seca no Nordeste do Brasil; "gente que, em sua grande maioria, trabalhava no campo produzindo alimentos" e que, em São Paulo, "depende da caridade para comer"; e pessoas que fazem parte das "dezenas de milhares de famílias brasileiras que vivem em acampamentos à beira das estradas em vários pontos do país", em situação "pior que a dos campos de refugiados na África”, e que integram o MST (Movimento dos Trabalhadores Rurais Sem-Terra), a quem foram cedidos os direitos autorais do livro - e do CD que o acompanha. ${ }^{19}$

Em sua interpretação de "Assentamento", Silva afirma: "A primeira leitura conduz imediatamente à oposição entre o campo e a cidade. Sim, mas o ponto central não é esse. 0 movimento pendular da canção, que 'zanza daqui, zanza pra acolá', não é geográfico, mas entre o ser/não ser de uma civilização. Ela é ao mesmo tempo canção do exílio e do retorno para casa, lamento de uma derrota e expressão de uma esperança que renasce, morte e vida - luto e reconciliação histórica" (pp. 130-131).

Como se vê, Silva considera que tanto a inspiração das fotografias quanto a finalidade do livro não são assim tão relevantes para o entendimento profundo da canção: mais importante é inseri-la no projeto estético de Chico, um entendimento aliás que parece acompanhar mais uma vez a

19 Cf. Salgado, Sebastião. Terra. São Paulo, Companhia das Letras, 1997, pp. 138-143. 
opinião do próprio artista; ou talvez não, mas isso não é importante aqui. ${ }^{20}$ Ocorre que as citações de Guimarães Rosa, que abrem e fecham a letra, e o ar jobiniano, que se sente na música, são destacados por Silva como, respectivamente, "imagens daquele que alcançou em sua obra - particularmente em Grande Sertão: Veredas - a síntese que o Brasil ficou devendo a si mesmo" e marcas de "uma promessa que o Brasil fez ao mundo, e ainda não cumpriu""21 (p.131). "Assentamento", enfim, para Silva configuraria "o Brasil que ficou suspenso no ar” (p. 132). Se a interpretação está correta, como fica o diálogo entre a utopia algo fantasmagórica dessa "espécie de "morto que não morre" (p. 131) ${ }^{22}$ e a situação concreta do MST, a qual é silenciada ao longo de toda a análise, mesmo tendo sido o estímulo inicial para a composição, via imagens fotográficas?

20 “A música 'Assentamento', por exemplo, as fotos do livro do Salgado (Terra) me serviram de motivação, de inspiração, ou o que você quiser, para escrever aquela música, mas ela foi criada dentro do meu universo poético, a partir daí eu fiquei satisfeito porque a música, enquanto música, entrou no livro do Salgado, e o livro tinha uma finalidade prática mesmo, até pecuniária, os direitos do livro foram cedidos para os semterra, aí é outra coisa. 'A música já está criada e vamos ver o que a gente faz com ela.' A gente cria um objeto de arte, a gente pode criar a partir dessa música uma utilidade prática, mas criar uma música pensando na sua finalidade objetiva me parece perigoso, empobrecedor mesmo." Cf. "Chico, o craque de sempre", entrevista a Caros amigos, São Paulo, Casa Amarela, ano 2, no 20, dez. 1998, p. 23. Vale lembrar, sobre o assunto, que já se tornou opinião corrente considerar várias canções de Chico como discursos que dão "voz àqueles que em geral não têm voz", conforme escreveu Adélia Bezerra de Meneses no início dos anos 80 (op. cit., pp. 118-128; ver também, da autora, Figuras do feminino. São Paulo, Ateliê Editorial/Boitempo, 2000, capítulo 2; e "Utopia renitente: Levantados do chão/Assentamento"; Cavalcante, Starling, \&t Eisenberg (orgs.), Decantando a República, volume III: A cidade não mora mais em mim. Rio de Janeiro, Nova Fronteira/ São Paulo, Ed. Fundação Perseu Abramo, 2004, pp. 113-122).

21 Como diz Fernando de Barros e Silva, em nota: "A frase é de Lorenzo Mammi, no prefácio do Cancioneiro Jobim (Rio de Janeiro, Jobim Music, 2000), p. $18 ”$.

22 Se não estou enganado, a expressão, referindo-se ali à "promessa histórica" cantada por Chico, bem como os próprios termos da interpretação de Silva para "Assentamento" retomam a seu modo o pensamento do crítico literário José Antonio Pasta Jr., originado em outro contexto: “essa contradição em ato que é o Brasil, cuja própria história, se assim se pode dizer, é a da alternância fastidiosa da construção e da ruína e, de certo modo, a conjunção de ambas, 'nação' indefinidamente límbica, que a barbárie faz tender entre impulsos contrários a Céu e Inferno, mas que o pêndulo parado da má-infinidade mantém, por isso mesmo, suspensa entre um e outro, num limbo ou limiar do além, sem que de todo ganhe um corpo ou o perca, sem que de todo ganhe ou perca uma 'alma'”. Cf. Pasta Jr., José Antonio. Pompéia (A metafísica ruinosa d'O Ateneu). São Paulo, FFLCH-USP, 1991, tese de doutoramento, p. 225. 
Caso optasse pelo diálogo, Silva faria jus a um princípio básico da democracia - o direito à fala e ao dissenso -, não importando qual fosse o seu posicionamento. Operando com o silêncio, Silva contorna, de modo um tanto autoritário, o choque que parece haver entre as utopias estética e social de pessoas esclarecidas e bem-postas na sociedade, que se sentem "uns desterrados em nossa terra" como formulou Sérgio Buarque, e a ação de "deserdados da terra", na expressão de Salgado. ${ }^{23}$

Fica assim a pergunta, que tenta sintetizar esse primeiro ponto que discuto: entre a omissão da existência de um movimento social organizado e a menção ao povo que faltou (à revolução?), o leitor mais atento não deveria refletir sobre o ponto de vista do livro, o qual também não examina o lugar social onde se realiza a obra de Chico Buarque?

Como segundo e último ponto, gostaria de chamar a atenção para os comentários de Silva sobre a parte musical das canções. Esse assunto é sempre muito delicado, pois no Brasil ainda são raros os estudos sobre canção popular que conseguem dar conta desse aspecto, integrando-o como etapa de uma interpretação mais ampla das obras. ${ }^{24}$ Nos jor-

23 Inspiro-me em uma passagem de Francisco de Oliveira: “Todo o esforço de democratização, de criação de uma esfera pública, de fazer política, enfim, no Brasil, decorreu, quase por inteiro, da ação das classes dominadas. Política no sentido em que a definiu [Jacques] Rancière (...): a da reivindicação da parcela dos que não têm parcela, a da reivindicação da fala, que é, portanto, dissenso em relação aos que têm direito às parcelas, que é, portanto, desentendimento em relação a como se reparte o todo, entre os que têm parcelas ou partes do todo e os que não têm nada”. Cf. "Privatização do público, destituição da fala e anulação da política: o totalitarismo neoliberal"; in: Oliveira, Francisco de \& Paoli, Maria. C. (orgs.), Os sentidos da democracia. 2a ed. Petrópolis (RJ), Vozes/ Brasília, Nedic, 1999, pp. 60-61.

24 Destaque-se, como um excelente exemplo, Feitiço decente, de Carlos Sandroni [Rio de Janeiro, Jorge Zahar Ed./ Ed. UFRJ, 2001]. Veja-se, por outro lado, que às vezes algum cochilo de análise põe em risco toda uma interpretação interessante, como ocorre no ensaio "Canção do exílio", de Lorenzo Mammì ( Nestrovski, Arthur et alii, Três canções de Tom Jobim. São Paulo, Cosac Naify, 2004, pp.12-29). Ótimo crítico, Mammì se equivoca na análise da harmonia de "Sabiá" (Tom Jobim/ Chico Buarque), não percebendo que a primeira parte, que ele diz estar na tonalidade de em Mi menor, na verdade começa na tonalidade de Ré Maior, modula para o VIo grau (Si menor, o relativo menor) e retorna a Ré Maior. Por conta desse erro, a sua conclusão de que "'Sabiá' é uma canção sem tonalidade definida, que acaba num lugar diferente daquele onde começa” também está um tanto equivocada. A terceira parte da canção termina na tonalidade de Ré menor, portanto próxima da inicial. 0 que ocorre é que o mais usual (e bastante comum) na música popular é o movimento inverso, parte inicial em menor, parte final no tom homônimo Maior, e com modulação bem definida separando as partes (como "Último desejo", de Noel Rosa, "Chega de saudade", de Tom e Vinicius, ou "Quem te viu, quem te vê", de Chico, à parte as especificidades de cada um desses casos). Já em relação às modu- 
nais, via de regra, ficamos na melhor das hipóteses com impressões de bons ouvintes, sem formação musical mas com intuição e muitas informações, o que por vezes gera pistas importantes para investigações mais criteriosas. No livro de Silva, esse é o caso da aproximação entre Chico e Jobim, na toada "Assentamento", ou do comentário sobre o arranjo de Rogério Duprat para “Construção” (p. 71), ou ainda da impressão, tomada de empréstimo a Pedro Alexandre Sanches, provocada pelo arranjo de "Bancarrota Blues" (p. 95), parceria de Chico com Edu Lobo.

A dificuldade aparece quando Silva mistura impressionismo a termos técnicos. Sobre "O futebol” (p. 111), por exemplo, se diz que "a música vai costurando em ziguezague, no sentimento diagonal de sua harmonia, uma espécie de jogada de movimentos perfeitos”, o que rigorosamente não quer dizer nada. Um outro exemplo: em meio a observações realmente perspicazes do autor sobre as letras de "Estação derradeira" e "Carioca" (pp. 126-128), afirma-se que esta última "tem uma das harmonias mais trabalhadas de toda a obra de Chico - um labirinto cromático, por onde se avança num ritmo rascado, feito de soluços, pequenos vácuos, movimentos bruscos e cortes inesperados - em oposição à melodia, que flutua no ar com leveza e alegria”. Ora, o ritmo do violão executando a harmonia é regular durante toda a canção (à parte a surpresa que causa, num primeiro momento, o fato de esse desenho rítmico, nos seus ataques de acordes, inverter a batida da marcha-rancho - esta, utilizada, por exemplo, em "Futuros amantes"). ${ }^{25}$ E o cromatismo auxilia no encadeamento dos acordes de uma harmonia

\footnotetext{
lações durante a segunda parte de "Sabiá", não se passa pela tonalidade de Si bemol menor, como o crítico afirma, mas do Ré Maior vai-se para Fá Maior (apenas por quatro compassos) e, daí, para Lá bemol Maior (simplificando, modulações para o IIIo grau do modo menor homônimo - mas com substituições bastante complexas de acordes, nos encadeamentos), de onde se volta para Ré Maior. (Devo essa análise harmônica a uma aula que tive com o maestro Cláudio Leal Ferreira, a quem dou crédito eximindo-o, obviamente, de qualquer responsável por aquilo que eu escrevi.)
}

25 A batida da marcha-rancho é quaternária, mas se a dividimos em duas partes (transformando um compasso $4 / 4 \mathrm{em}$ dois $2 / 4$ ), teremos duas células rítmicas de ataques de acordes (desprezo aqui, para efeito de análise, tanto os bordões como as notas abafadas). Essas células trocam de ordem na batida de "Carioca", resultando numa estilização original do samba-reggae; ou, nas palavras do músico Luiz Claudio Ramos (arranjador dos trabalhos recentes de Chico Buarque), resultando num ritmo que é "meio bossa nova, meio Olodum":

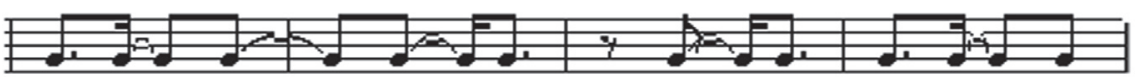


tonal, ou seja, na chamada "condução das vozes", o que mereceria ser analisado mas nada tem de labiríntico.

Sei que talvez eu esteja exagerando no nível de exigência diante de um livro que realmente contribui, com qualidade e dentro de seus limites, para o conhecimento da obra de Chico Buarque. Acontece que equívocos assim espantam os músicos, cuja melhor reação acaba sendo a indiferença - o que não é justo, pois se trata de um trabalho que merece ser discutido. 